\author{
Marcin Berdyszak \\ Uniwersytet Artystyczny w Poznaniu \\ marcin_berdyszak@wp.pl
}

\title{
SZTUCZNY INSTYNKT KULTURY
}

W powieści Spadkobiercy Wiliama Goldinga mamy do czynienia z dwoma plemionami ludzkimi - Neandertalczykami i ludźmi z Cromagnon, którzy są inteligentniejsi, co potwierdzają badania antropologiczne. W utworze Goldinga wydaje się, że w walce o byt zwycięża plemię inteligentniejsze. Inteligentniejsze i zdecydowanie agresywniejsze. To inteligencja rodzi agresję. Agresja zatem zastępuje instynkt przetrwania, który był tak silny dla Neandertalczyka. Instynkt, którym posługiwał się Neandertalczyk, wykluczał - według Goldinga - agresję i zakładał harmonię z naturą. Eugène Marais, południowoafrykański badacz z przełomu XIX i XX wieku, twierdził, że inteligencja jest czymś, czym nadrabiamy brak instynktu. Mówimy o sztucznej inteligencji, ale czy istnieje, albo istnieć może, sztuczny instynkt?

Zatem inteligencja jest wypadkową braku gotowości na niespodziewane. Gdy stwierdzimy, że człowiek z natury jest inteligentny, to tak jakbyśmy stwierdzili, że w naturze naszej leży bycie permanentnie nieprzygotowanym na niespodziewane. W kontekście instynktu chyba nie możemy mówić o problemie nieprzygotowania...

Tymczasem szeroko pojęta kultura zawłaszcza nawet to, co nieoczekiwane, estetyzuje je, zanim zostanie rozpoznane. Wytwarza się sytuacja, w której nasza partycypacja polega na instynktownym działaniu. To instynktowne działanie nie pochodzi jednak od natury, z którą instynkt był zawsze utożsamiany, lecz źródło swe ma w represyjnej kulturze popularnej. 


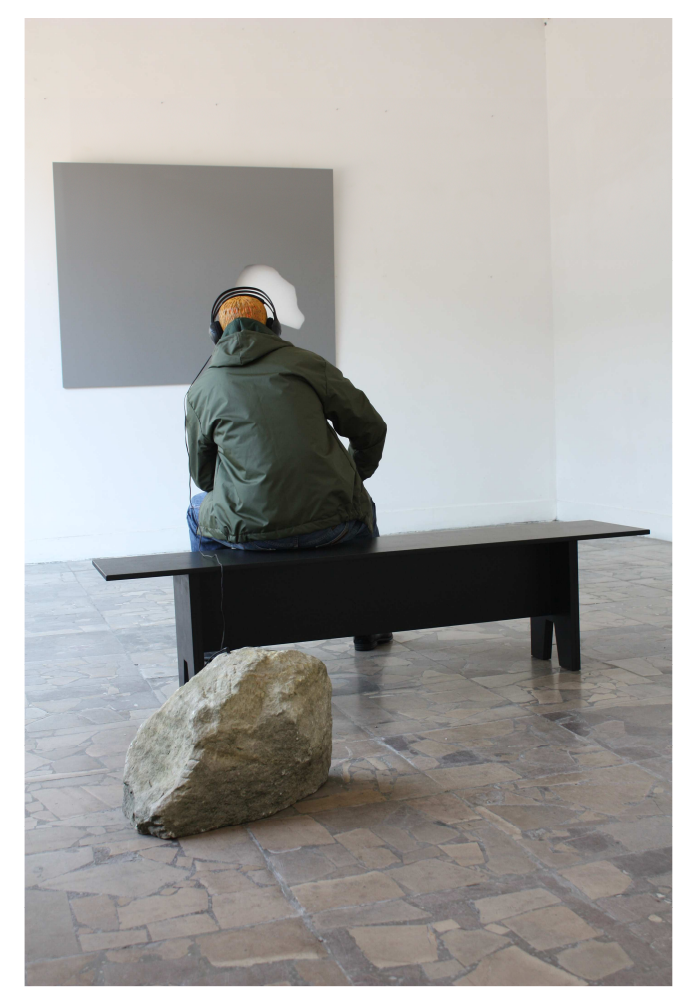

Marcin Berdyszak, Opór i zaślepienie, czyli Odyseusz i Syreny (Realizacja dedykowana twórczości mojego ojca Jana Berdyszaka), (2014) ${ }^{1}$

Zatem możemy mówić o „sztucznym” instynkcie kultury, któremu ulegamy, instynktownie reagując na szerokie oferty czy presje kultury popularnej, takie jak powszechna estetyzacja, korzystanie z promocji - kupujemy, bo jest taniej niż zwykle, niezależnie, czy tego potrzebujemy, czy nie, wreszcie pijemy napoje bądź jemy, bo są ku temu warunki, jak stacja BP, McDonald's czy automat do kawy. Zatem pragnienie nie będzie już tylko instynktem utożsamianym z naturą, ale również instynktem kulturowym. Taki stan sugeruje, że albo rozszerzymy pojecie instynktu, nie dzieląc go na naturalny i kulturowy, albo instynkt kultury będziemy traktować jako sztuczny, bo wypracowany przez kulturę i przystający do pojęcia sztucznej inteligencji. Skoro zatem mamy do czynienia z takimi pojęciami jak sztuczna inteligencja i sztuczny instynkt, to gdzie lokuje się istnienie, które z nich korzysta? Czy są to roboty, humanoidy, czy jakaś inna forma życia? Otóż to my sami najpierw ujarzmiający naturę, a w konsekwencji ujarzmieni przez kulturę,

${ }^{1}$ Wszystkie ilustracje pochodzą od autora tekstu (przyp. red.). 
która podpowiada, poprzez nabywane przez nas "nowe instynkty”, jak w niej funkcjonować - musi podpowiadać, gdyż te "stare" instynkty przetrwania są $\mathrm{w}$ jej ramach bezużyteczne, a raczej niekompatybilne względem niej. Jednym słowem, potrzebne są i jedne, i drugie, przynajmniej na chwilę obecną. Idąc dalej, konieczne stanie się traktowanie błędu, usterki, awarii w systemie jako następstwa grzechu pierworodnego. Argument niedoskonałości jest najpoważniejszym argumentem realnego istnienia, bo istnienie posiadające „body" lub jego brak musi się doskonalić.

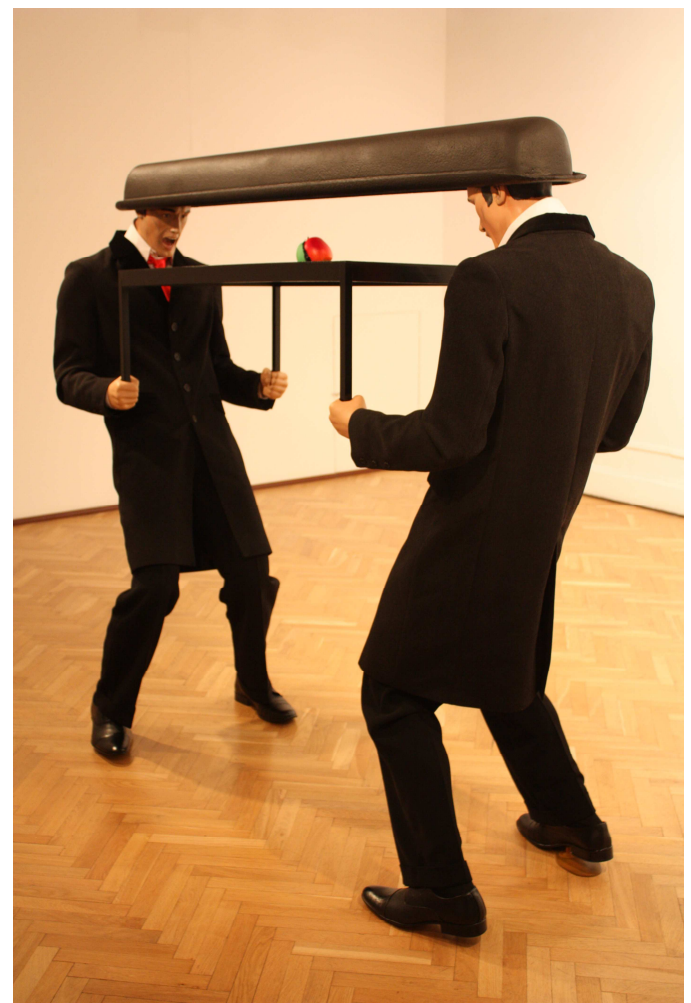

Marcin Bardyszak, Syn człowieczy Magritte'a i symulacje (2013)

Anonimowość zarówno dziecka, jak i dorosłego, można zauważyć w pracach amerykańskiego artysty Georga Segala, który w latach 60. tworzył swoje rzeźby będące rodzajem zamrożonego teatru. Realizacje Segala polegały na ustawianiu anonimowych figur w kontekście anonimowych sytuacji - na przykład figura wyciągająca puszkę coca-coli z automatu lub gipsowa postać, reprezentująca każdego z nas, siedząca na przystanku 
i czekająca na autobus. Te prozaiczne sytuacje, w których zdarza się znaleźć każdemu, ukazują częstotliwość naszej anonimowości w kulturze dnia codziennego. Podpowiadają one nam wręcz nasze zachowanie i czynności, które należy wykonać - żeby gdzieś się przemieścić, jeśli czekamy na autobus, albo żeby ugasić pragnienie, jeśli faktycznie jesteśmy spragnieni, bo może to automat $\mathrm{z}$ napojami powoduje fakt kulturowego odczuwania pragnienia na skutek samej swej obecności? To zachowanie i te czynności nie wynikają wyłącznie z naszej ekspresji, refleksji czy też biologicznych uwarunkowań. Często nie wynikają też z naszej woli. Powtarzalność tych sytuacji jest kolosalna dla każdego indywidualnie - począwszy od bycia małym dzieckiem, które coś chce, bo akurat to widzi, po moment bycia dorosłym, który na przykład coś kupuje, bo kiedyś tam może mu się to przydać. Powtarzalność tych sytuacji jest ogromna, biorąc pod uwagę zwykłą statystykę.

Można stwierdzić, że bierzemy udział w jakimś projekcie albo mamy pewną rolę do odegrania. Wymuszoną kulturowo role spragnionego, pasażera, kupującego w markecie, czekającego na odprawę celną lub w kolejce do dentysty. Cel jest jasny: ugasić pragnienie, które trudno jednoznacznie zaklasyfikować jako naturalnie naturalne albo jako kulturowo naturalne, a które definiuję jako wynik działania sztucznego instynktu kultury.

Chcąc się napić, musimy wrzucić 2 złote do automatu, następnie uchylić szybkę i wyjąć butelkę lub puszkę. Gdy nie mamy drobnych, to musimy rozmienić pieniądze, a gdy to się nie powiedzie - pozostaje nam zaniechanie. Scenariusz jest wytyczony bez wzglądu na to, czy cel zostanie osiągnięty, czy też nie. Dobrze wiemy, że często próbujemy do oporu, bez względu na rezultat. Dotyczy to zarówno dorosłych, jak i dzieci.

Kulturowa naturalność, czyli przyjmowanie gotowych ofert i posłuszna partycypacja $w$ ich realizacji, jest typowa dla postawy Kampa, określonego przez Susan Sontag jako dandysa kultury masowej. „Kampizm” daje pozory wyrafinowania.

Pozór zatem staje się wzorem, matrycą do naśladowania - choć dzieje się to tak naprawdę $\mathrm{w}$ imię naszej nieobecności, którą tym bardziej podkreślamy, im bardziej partycypujemy w kulturze masowej.

Problem trwałości, niezniszczalności czy wieczności kultura ta podejmuje w sobie właściwy sposób również poprzez imitacje i substytuty, których podobieństwo czy wręcz identyczność jest pozorna, tak jak pozorny jest plastikowy banan w stosunku do prawdziwego.

Realizacje Tony'ego Cragga uświadomiły i zmieniły synonim trwałości w kulturze na początku lat 80. Trwałość, ta nieproporcjonalna w stosunku do człowieka realna obecność, przypisywana jak dotąd skałom, kamieniom, 
została zamieniona na plastik - trudny do utylizacji, niezniszczalny. Jak się okazało, trzeba było zużyć znaczną część wiedzy i energii, aby ten nowy synonim trwałości nas nie zniszczył.

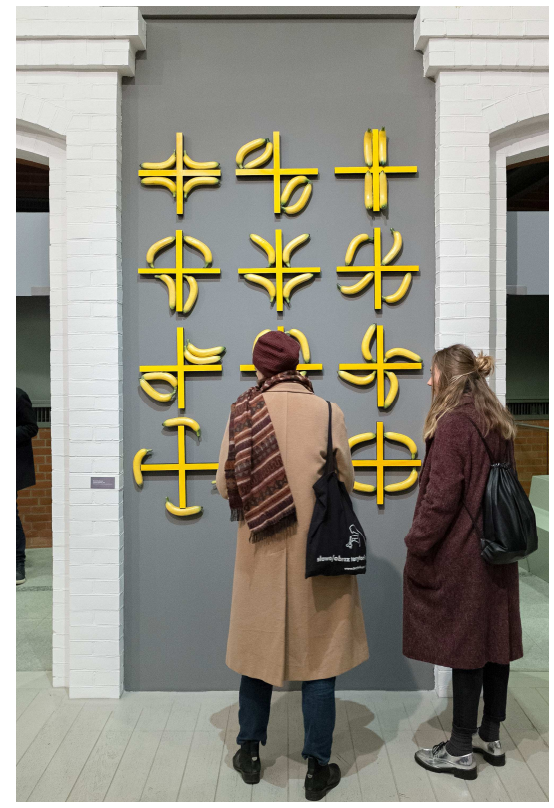

Marcin Berdyszak, Analfabet (fragment) (2016)

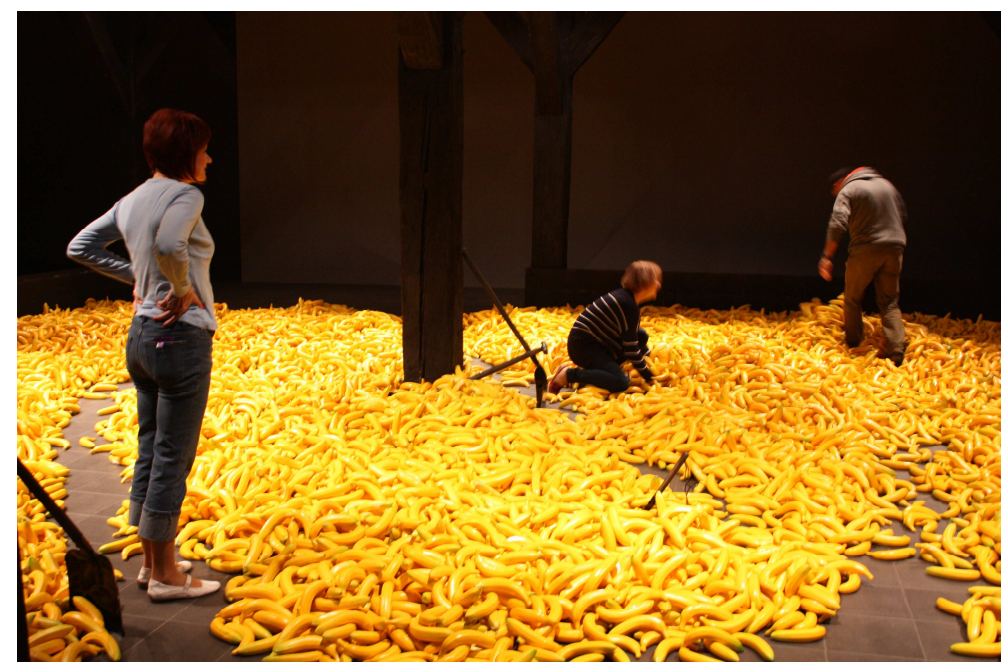

Marcin Berdyszak, Praktyki codzienne w czasach konsumpcji (2014) 
Kolejnym synonimem trwałości jest Internet, w którym, mimo naturalnej śmierci, ciągle istnieją ślady naszej obecności. Fenomen wieczności, wiecznego życia, dotyczy zatem innego świata. Nie może on dotyczyć świata ziemskiego, bo wieczność, rozumiana w kategoriach ziemskich, a więc i kulturowych, mogłaby być nieetyczna, tak samo jak produkowanie bardzo trwałych urządzeń, których byśmy nie musieli ciągle wymieniać na nowe. Wtedy bowiem ludzie nie mieliby co produkować, a konsekwencji - nie mogliby i nie musieli zarabiać, i koło zostałoby przerwane. Okazuje się, że tu, gdzie teraz jesteśmy, nietrwałość jest koniecznością, co więcej - jest etyczna. Wydłużanie życia ludzkiego jest priorytetem nauk medycznych, $i$ jest to całkowicie logiczne moralne i zrozumiałe, jednak będzie to rodzić kolejne nieprzewidziane skutki. Być może 80 letni wnuczek będzie musiał konkurować o pracę ze swoim 140 letnim dziadkiem. Umiejscowienie wieczności poza życiem doczesnym jest jedyną sensowną możliwością posiadającą silną moc perswazyjną dla żyjących tu i teraz. Śmierć, jako doświadczenie nieprzekazywalne, intensyfikuje i urealnia możliwość życia wiecznego.

DOI: 10.14746/cbes.2016.15.21 